\title{
ASSESSMENT OF FRACTURE MOMENT AND FRACTURE ANGLE IN 25 TREE SPECIES IN THE UNITED STATES USING THE FRACTOMETER
}

\author{
by Nelda P. Matheny, ${ }^{1}$ James R. Clark, ${ }^{1}$ Donna Attewell, ${ }^{2}$ Kevin Hillery, ${ }^{2}$ \\ A. William Graham, ${ }^{3}$ and Gerald Posner ${ }^{4}$
}

\begin{abstract}
The fracture moment and fracture angle of core samples from the lower trunk of 25 tree species were evaluated using the Fractometer, a device developed at the Nuclear Research Institute, Karlsruhe, Germany. In 6 additional species, core segments broke upon initial loading in the Fractometer and values could not be obtained. Fracture moments and angles were recorded for trees located in California, Oregon, Pennsylvania, and Illinois. Results varied by species, core segment, and location of tree. Application of the Fractometer to tree hazard evaluation procedures is discussed.
\end{abstract}

The evaluation of structural defects in trees and the assessment of failure potential often involves detecting decay and evaluating the resulting loss of wood strength. Arborists can readily observe advanced decay by noting changes in wood color and texture. The early and incipient stages of decay, however, are generally impossible to detect visually. In these stages wood may appear normal, with little or no change in color or texture, yet wood strength may be significantly reduced (Wilcox 1978). Therefore, techniques that would permit assessment of wood strength before visual changes occurred would increase the accuracy of decay detection.

The Fractometer is an instrument that measures the elasticity and fracture strength of wood and may be used in evaluating the presence of decay in the trunk and other woody parts (Mattheck et al, 1994, 1995). An increment core is removed from the tree and placed in the Fractometer. The sample is stressed to the point of failure by increasing the force pushing against it. The Fractometer provides the fracture moment (M) and angle of failure $(\phi)$ for the sample. These can be then compared to known standards (Mattheck et al. 1994, 1995) and to decay-free samples taken from the same tree. Mattheck et al. (1994) presented results for a number of European genera. There was a wide range in values, particu- larly for fracture moment. As an example, results for Douglas-fir (Pseudotsuga menziesii) ranged from 5 to 9, whereas results for ash (Fraxinus spp.) ranged from 7 to 120 .

Mattheck et al. (1994) concluded that large fracture moments and small fracture angles were indicative of sound wood, not acted upon by decay. Deviations from this situation, such as decrease in fracture moment, increase in fracture angle, or a combination of the two, were due to the presence of decay. Moreover, the relative values of fracture moment and angle were indicative of the general type of decay present, either white or brown rot. In a subsequent analysis, Mattheck et al. (1995) proposed interpretive guidelines for Fractometer results, suggesting that reference values for genera could be used to determine the failure potential.

Application of these results and use of the Fractometer in the United States and Canada have been limited by the lack of both experience with the device and the availability of comparative standard results. The research described in this paper addresses these issues.

\section{MATERIALS AND METHODS}

Thirty-one tree species were sampled in the following locations:

California:

Street and park trees, cities of Pleasanton, Livermore, and San Francisco

Illinois: Morton Arboretum, Lisle

Oregon: Hoyt Arboretum, Portland; Lone Fir Cemetery, Portland; Jenkins Estate, Portland

Pennsylvania: Morris Arboretum, Philadelphia

In general, sampled trees were healthy and free from known trunk defects. Increment cores were taken from the windward and leeward sides of the trunk, at 
a height from 1 to $1.5 \mathrm{~m}$ ( 3.3 to $5 \mathrm{ft}$ ) above ground. Cores were $4.3 \mathrm{~mm}$ $(0.16 \mathrm{in}$.) wide and ranged from 20 to $30 \mathrm{~cm}$ ( 8 to 12 in.) in length. Upon removal from the tree, the entire core was inserted into the Fractometer with 2 to $3 \mathrm{~cm}(0.8$ to $0.12 \mathrm{in}$.) protruding from the device's lever arm. The load on the lever arm was quickly increased to the point of core breakage, whereupon the fracture moment and angle were recorded. The procedure was repeated at 2 - to $3-\mathrm{cm}$

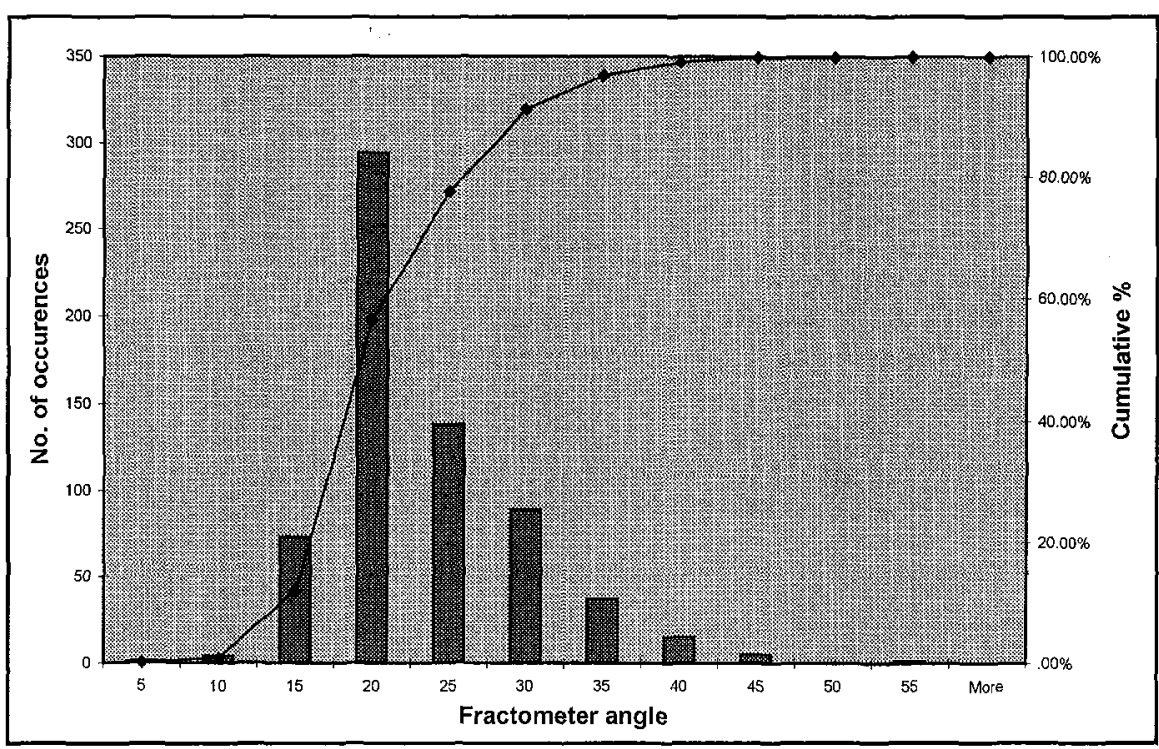

Figure 2. Frequency and cumulative percentage of fracture angle results. increments along the length of the core segment. In general, each increment core yielded 5 samples. Each segment with the core was numbered corresponding to its position relative to the bark. Core segment \#l was closest to the bark and \#5 was the most interior.

\section{RESULTS}

Fractometer readings could not be obtained for 6 species: Monterey cypress (Cupressus macrocarpa), blue gum (Eucalyptus globulus), ponderosa pine

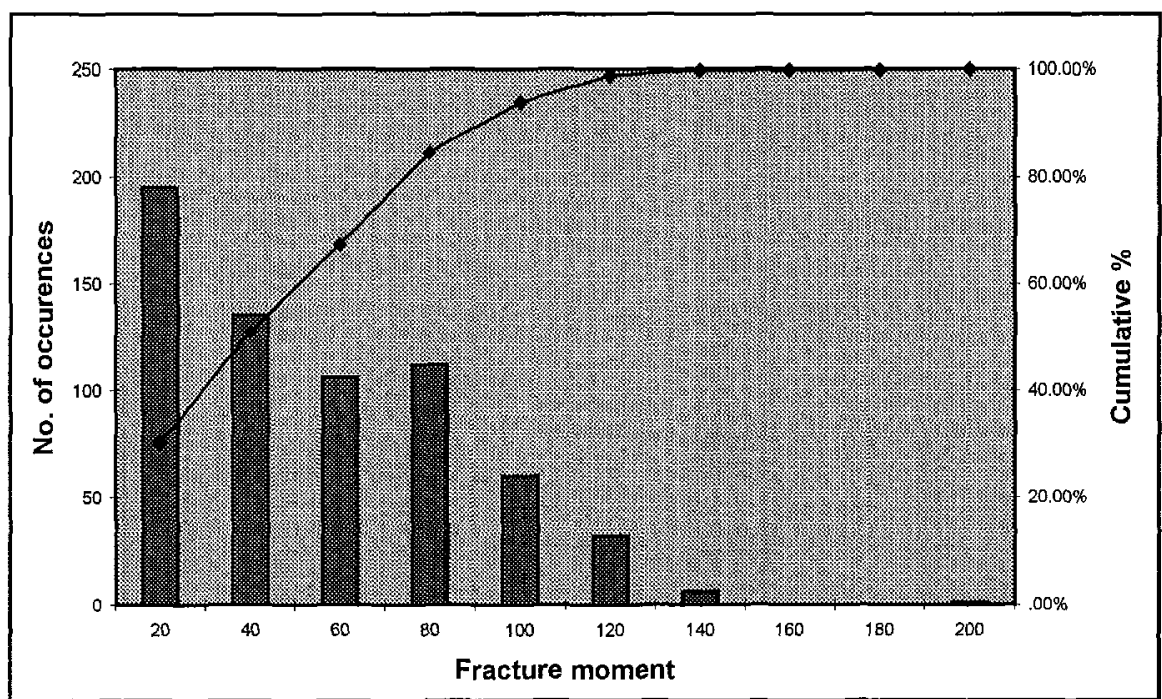

Figure 1. Frequency and cumulative percentage of fracture moment results.
(Pinus ponderosa), black cottonwood (Populus trichocarpa), Douglas-fir (Pseudotsuga menziesii), and coast redwood (Sequoia sempervirens). In these species, core segments broke when the lever arm was initially placed against the sample. No measurable results could be obtained. For Monterey pine, fracture moment readings were recorded but fracture angles were not obtained.

Fractometer readings were obtained from 25 species (Table 1). In some cases, the first segment in the core (adjacent to the bark) broke before any readings could be obtained (see "No. of samples" column in Table 1). As a result, readings were obtained from a total of 647 core segments.

Standard methods of statistical analysis are based upon the assumption that data points are distributed normally around a mean. Before applying any statistical tests to the data, we determined whether results obtained with the Fractometer were normally distributed. To do so, we 
Table 1. Fractometer readings (fracture moment and angle) for 25 species.

\begin{tabular}{|c|c|c|c|c|c|c|c|c|c|}
\hline \multirow{4}{*}{$\begin{array}{l}\text { Common } \\
\text { name }\end{array}$} & \multirow{4}{*}{$\begin{array}{l}\text { Scientific } \\
\text { name }\end{array}$} & \multirow[b]{4}{*}{ Location } & \multirow{4}{*}{$\begin{array}{l}\text { No. of } \\
\text { trees }\end{array}$} & & & \multicolumn{4}{|c|}{ Fractometer results } \\
\hline & & & & \multirow{2}{*}{\multicolumn{2}{|c|}{ No. of samples }} & \multirow{3}{*}{$\begin{array}{l}\text { Fracture } \\
\text { moment } \\
\text { * range }\end{array}$} & \multicolumn{3}{|c|}{ Fracture angle } \\
\hline & & & & & & & \multicolumn{3}{|c|}{ Std. error } \\
\hline & & & & Measured & Broken* & & Mean & of mean & Range \\
\hline Bigleaf maple & Acer macrophyllum & OR & 3 & 27 & 3 & $5-41$ & 23.2 & 0.6 & $20-31$ \\
\hline \multirow[t]{3}{*}{ Norway maple } & Acer platanoides & $\mathrm{IL}$ & 3 & 25 & 5 & $5-38$ & 25.6 & 1.2 & $17-45$ \\
\hline & & OR & 4 & 33 & 2 & $9-48$ & 28.8 & 1.1 & $21-45$ \\
\hline & & PA & 3 & 28 & 2 & $24-99$ & 17.1 & 0.3 & $14-21$ \\
\hline Red maple & Acer rubrum & $\mathrm{PA}$ & 3 & 26 & 4 & $46-114$ & 16.7 & 0.3 & $15-20$ \\
\hline Sugar maple & Acer saccharum & $\mathrm{PA}$ & 4 & 37 & 3 & $13-191$ & 16.3 & 0.3 & $13-20$ \\
\hline Deodar cedar & Cedrus deodara & $\mathrm{CA}$ & 3 & 16 & 14 & $3-61$ & 23.2 & 1.1 & $18-32$ \\
\hline Hackberry & Celtis occidentalis & $\mathrm{PA}$ & 1 & 10 & 0 & $54-70$ & 19.3 & 0.6 & $16-22$ \\
\hline White ash & Fraxinus americana & $\mathrm{PA}$ & 3 & 25 & 5 & $8-91$ & 16.2 & 0.5 & $11-25$ \\
\hline \multirow[t]{2}{*}{ European ash } & Fraxinus excelsior & IL & 2 & 11 & 9 & $19-74$ & 24.1 & 1.2 & $20-30$ \\
\hline & & $\mathrm{PA}$ & 1 & 10 & 0 & $28-72$ & 17.7 & 1.4 & $8-24$ \\
\hline Black ash & $\begin{array}{l}\text { Fraxinus nigra } \\
\text { var. nigra }\end{array}$ & PA & 1 & 9 & 1 & - & 27.1 & 2.1 & $20-40$ \\
\hline Modesto ash & $\begin{array}{l}\text { Fraxinus velutina } \\
\text { 'Modesto' }\end{array}$ & $\mathrm{CA}$ & 3 & 27 & 3 & $2-50$ & 23.5 & 0.7 & $18-30$ \\
\hline Honey locust & $\begin{array}{l}\text { Gleditsia } \\
\text { triacanthos f. inermi }\end{array}$ & PA & 3 & 30 & 0 & $12-119$ & 18.9 & 0.8 & $2-26$ \\
\hline Black walnut & Juglans nigra & $\mathrm{PA}$ & 2 & 20 & 0 & $21-68$ & 15.8 & 0.2 & $15-18$ \\
\hline \multirow[t]{2}{*}{ Sweetgum } & Liquidambar & OR & 2 & 12 & 8 & $8-61$ & 28.8 & 1.6 & $20-40$ \\
\hline & styraciflua & PA & 2 & 18 & 2 & $2-54$ & 16.8 & 0.7 & $13-25$ \\
\hline \multirow[t]{2}{*}{ Tuliptree } & Liriodendron & OR & 3 & 27 & 3 & $1-22$ & 26.1 & 0.7 & $19-36$ \\
\hline & tulipifera & PA & 3 & 26 & 4 & $38-83$ & 17.0 & 0.6 & $12-29$ \\
\hline Monterey pine & Pinus radiata & $\mathrm{CA}$ & 3 & 4 & 26 & $25-30$ & - & - & - \\
\hline \multirow[t]{2}{*}{ London plane } & Platanus $\times$ & $\mathrm{CA}$ & 3 & 30 & 0 & $8-68$ & 24.2 & 0.6 & $15-29$ \\
\hline & acerifolia & $\mathrm{PA}$ & 1 & 9 & 1 & $63-97$ & 16.5 & 0.9 & $10-20$ \\
\hline White oak & Quercus alba & PA & 3 & 30 & 0 & $22-116$ & 15.5 & 0.3 & $11-18$ \\
\hline Oregon oak & Quercus garryana & OR & 1 & 10 & 0 & $21-66$ & 31.0 & 0.4 & $30-32$ \\
\hline Valley oak & Quercus lobata & $\mathrm{CA}$ & 4 & 34 & 6 & $3-80$ & 21.6 & 0.6 & $16-33$ \\
\hline Pin oak & Quercus palustris & $\mathrm{PA}$ & 3 & 25 & 5 & $62-135$ & 18.5 & 0.5 & $14-25$ \\
\hline Red oak & Quercus rubra & PA & 3 & 27 & 3 & $37-137$ & 16.7 & 0.6 & $9-21$ \\
\hline \multirow[t]{2}{*}{ Littleleaf linden } & Tilia cordata & OR & 3 & 24 & 6 & $2-14$ & 32.2 & 0.7 & $27-38$ \\
\hline & & $\mathrm{PA}$ & 1 & 7 & 3 & $10-24$ & 21.7 & 1.0 & $19-25$ \\
\hline American elm & Ulmus americana & OR & 4 & 16 & 24 & $2-18$ & 34.4 & 1.7 & $28-55$ \\
\hline Siberian elm & Ulmus pumila & $\mathrm{CA}$ & 3 & 27 & 13 & $2-15$ & 25.1 & 1.3 & $17-42$ \\
\hline Japanese zelkova & Zelkova serrata & $\mathrm{PA}$ & 1 & 5 & 5 & $67-100$ & 20.1 & 1.4 & $18-19$ \\
\hline
\end{tabular}

*Segments that broke when the lever arm was released, before a reading could be taken.

plotted the results as frequency distributions (Figures 1 and 2). Although no specific quantitative tests were performed to evaluate normality, cumulative percentage plots are an accepted method of doing so (Sokal and Rohlf 1969). Results for the fracture moment values did not adhere to the $\mathbf{S}$-shaped curve expected from a normal distribution (Figure 1). Fracture moment data were strongly skewed to the right or lower values. As a result, only the range of fracture moment results are presented. In contrast, fracture angle data appeared normally distributed (Figure 2) and estimates of sample variation were made (Table 1 ). 


\section{Fracture Moments}

Fracture moment measurements were highly variable (Table 1), Values ranged from 2 to 14 for littleleaf linden (Tilia cordata) and from 13 to 191 for sugar maple (Acer saccharum). Fracture moment values for a single species measured in different locations also varied widely. For example, we obtained results for Norway maple (Acer platanoides) in 3 locations; the values ranged from 5 to 38 in Illinois, 9 to 48 in Oregon, and 24 to 99 in Pennsylvania. Similar variation was obtained in

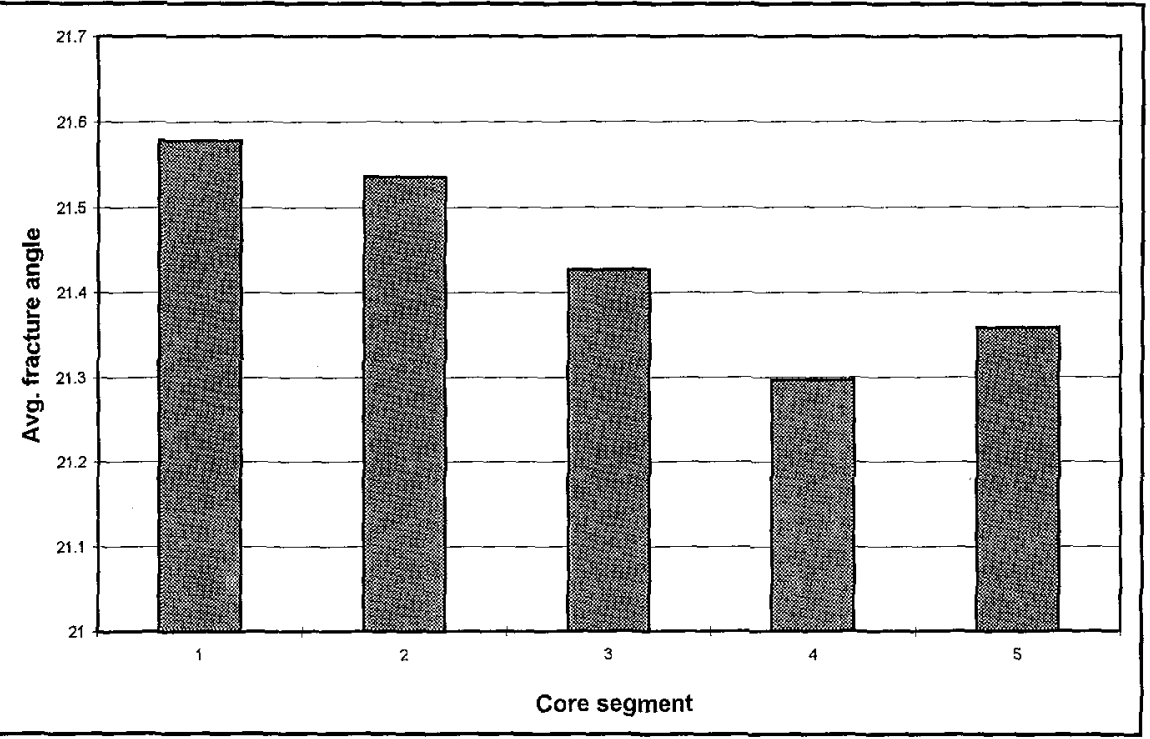

Figure 3. Fracture angle results by core segment. Average of all species. Segments are numbered from exterior (1) to interior (5). tuliptree (Liriodendron tulipifera), European ash (Fraxinus excelsior), London plane (Platanus $x$ acerifolia), and littleleaf linden. In contrast, fracture moment values for sweetgum (Liquidambar styraciflua) were similar between Oregon and Pennsylvania.

\section{Fracture Angle}

Fracture angle results were less variable than those for fracture moments (Table 1). Average values for individual species ranged from a low of $15.5^{\circ}$ in white oak (Quercus alba) to a high of $34.4^{\circ}$ in American elm. Results for a single species growing in different locations were also quite variable (compare sweetgum in Oregon and Pennsylvania, Table 1). However, in some species, fracture angles were consistent between locations (compare Norway maple [Acer platanoides] in Illinois, Oregon, and Pennsylvania).

Unlike the fracture moment, fracture angles decreased with increasing depth of the core (Figure 3 , average values for all species). Core segments from just beneath the bark had a higher fracture angle than segments taken at greater depth (compare segment 1 to segment 4, Figure 3). The absolute difference in angle was very small, less than $0.3^{\circ}$.

Statistical analysis of the fracture angles was complicated for 2 reasons. First, samples were not independent of each other. Second, the sample population for each core segment varied between
121 (segment 1) and 142 (segment 3) with numerous missing values. We choose not to estimate missing values. The standard errors of mean for each core segment (standard deviation/square root of $\mathrm{N}$ ) were large enough to suggest that there were not significant differences among core segments (data not presented).

\section{DISCUSSION}

The goal of this project was to survey a range of North American trees species for results using the Fractometer. We measured the fracture moment and fracture angle for 25 taxa growing in the United States. The range in values found in testing is broadly comparable to those of Mattheck et al. (1975).

However, there are several important differences between our 2 surveys. First, samples from 6 species broke before readings could be obtained. Included in this group were 2 species, Douglas-fir and black cottonwood, assessed by Mattheck et al. (1994). Second, results from individual species were not always similar. For example, Mattheck reported that London plane had fracture moments ranging from 88 to 120 and bending angles from $10^{\circ}$ to $23^{\circ}$. Our results for this species were 8 to 97 and $10^{\circ}$ to $29^{\circ}$ (in California and Pennsylvania). Similarly, with 2 species of elm in our study, we found fracture moments of 2 to 18 and fracture angles of $17^{\circ}$ to $55^{\circ}$. Mattheck found 
fracture moments and fracture angles ranging from 23 to 78 and $10^{\circ}$ to $22^{\circ}$, respectively.

Some of this variation might be associated with testing different species within a genus. Mattheck identified trees tested only by genera. In addition, there appeared to be significant variation in Fractometer results due to location. Factors such as climate, soil, available moisture, exposure to wind, past loading by snow and ice, and growth rate could be the source(s) of such variation. Mattheck (personal communication) has also observed results to be location dependent.

Given the variation in results among geographic locations and within individual species, arborists using the Fractometer must focus on samples taken from individual trees rather than on tables of standardized results. In evaluating the strength loss associated with decay, Fractometer values must be compared to results from decay-free samples taken from the same tree. In this case, results from sound wood can be compared to those from wood acted upon by decay fungi. Arborists must be cautioned that use of the Fractometer in evaluating strength loss, structural stability, and application of abatement and remedial treatments must be based upon results obtained from individual trees.

Because of the variable nature of the data and its lack of normality, we were reluctant to apply statistical analysis to the results. For this reason, some observations could not be adequately interpreted. For example, fracture moment appeared to vary by location within the core with the segment nearest the bark having a lower value than the 4 segments interior to it (data not presented). Additionally, in species such as American elm (Ulmus americana) and tuliptree, interior segments from several samples were discolored. We were not able to determine if this discoloration was associated with strength loss as measured by the Fractometer.

\section{LITERATURE CITED}

Mattheck, C., H. Breloer, and K. Bethge. 1994. A guide to Fractometer tree assessment. Arb. News 3(2):9-12.

Mattheck, C., H. Breloer, K. Bethge, W. Albrecht, and A. Zipse. 1995. Use of the Fractometer to determine the strength of wood with incipient decay. J. Arboric. 21(3):105-112.

Sokal, R., and F. Rohlf. 1969. Biometry. The Principles and Practice of Statistics in Biological Research. W.H. Freeman, San Francisco, CA. 776 pp.

Wilcox, W. 1978. Review of literature on the effects of early stages of decay on wood strength. Wood Fiber 9(4): 252-257.

Acknowledgements. Authors appreciate the cooperation of Ed Murdock (Livermore, California), Mike Fulford (Pleasanton, California), Fred Nilsen (Portland, Oregon), Stephen Peacock (Portland, Oregon), and Alan Wells (Portland, Oregon) in providing trees used for analysis. We also acknowledge the support of Ed Brennan and Elinor Goff in collecting data. Reviews by Claus Mattheck and 2 anonymous reviewers were particularly helpful. The assistance of Dan Struve in discussing appropriate statistical analysis was greatly appreciated. The Fractometer was kindly provided by Dr. Mattheck. This project was funded in part by the Karlsruhe Nuclear Research Center, Karlsruhe, Germany.

${ }^{1}$ Hort Science, Inc.

P.O. Box 754

Pleasanton, CA 94566

${ }^{2}$ Whole Tree Works

2822 S.E. Belmont

Portland, OR 97214

${ }^{3}$ Morris Arboretum of the University of Pennsylvania

9414 Meadowbrook Avenue

Philadelphia, PA 19118

${ }^{4}$ Arbor-Cultural Consultants \& Associates

328 Flatbush Avenue

Brooklyn, NY 11238 
Résumé. Des échantillons de 31 espèces d'arbres ont été évalués au moyen du Fractomètre, appareil développé à l'Institut de recherche nucléaire de Karlsruhe en Allemagne. Les moments et les angles de fracture ont été consignés à partir d'arbres provenant de Californie, d'Oregon, de Pennsylvanie et d'Illinois. Les résultats varient selon les espèces le segment échantillonné et la localisation de l'arbre. Lapplication du Fractomètre aux procédures d'évaluation d'arbres est discutée.

Zusammenfassung. Unter Einsatz eines Fractometers (entwickelt am Kernforschungszentrum in Karlsruhe, Deutschland) wurde das Bruchmoment und der Bruchwinkel von Bohrkernen aus dem unteren Stammbereich von 25 Baumarten untersucht. Bei 6 zusätzlichen Arten brachen die Bohrkerne sofort nach dem Bestücken des Fractometers, so daß hier keine Daten gewonnen werden konnten. Das Bruchmoment und der Winkel wurden bei Bäumen aus Kalifornien, Oregon,
Pennsylvanien und Illinois gemessen. Die Ergebnisse variierten in Abhängigkeit von der Baumart, Bohrkern und Standort. Die Anwendung des Fractometers bei der Bewertung von Bäumen befindet sich in Diskussion.

Resumen. Se evaluaron el ángulo y el momento de fractura de probetas de madera extraídas de la parte baja del tronco de 25 especies de árboles usando el Fractómetro, un aparato desarrollado en el Instituto de Investigación Nuclear, Karlsruhe, Alemania. En 6 especies adicionales, los segmentos de probeta se rompieron al inicio de la carga en el Fractómetro y no pudieron obtenerse los valores. Se registraron los ángulos y los momentos de fractura de árboles localizados en California, Oregón, Pennsylvania e Illinois. Los resultados variaron por especies, los segmentos de las probetas y el sitio del árbol. Se tratan los procedimientos de aplicación del Fractómetro para evaluar los árboles de riesgo. 